ISSN: 2302-8556

E-Jurnal Akuntansi Universitas Udayana

Vol.24.1.Juli (2018): 662-686

DOI: https://doi.org/10.24843/EJA.2018.v24.i01.p25

\title{
Pengaruh Pendapatan Asli Daerah terhadap Pertumbuhan Ekonomi dengan Belanja Modal dan Investasi Swasta sebagai Pemoderasi
}

\author{
Ida Ayu Saraswati ${ }^{1}$ \\ I Wayan Ramantha ${ }^{2}$ \\ ${ }^{1}$ Fakultas Ekonomi dan Bisnis Universitas Udayana (Unud), Bali, Indonesia \\ email: dayucharly@yahoo.com/ Telp: +62 89605213986 \\ ${ }^{2}$ Fakultas Ekonomi dan Bisnis Universitas Udayana (Unud), Bali, Indonesia
}

\begin{abstract}
ABSTRAK
Pertumbuhan Ekonomi merupakan salah satu indikator untuk mengukur keberhasilan pembangunan ekonomi dalam suatu negara. Diharapkan dengan adanya penerimaan dari PAD dapat meningkatkan Pertumbuhan Ekonomi daerah, peningkatan PAD dapat meningkatkan Belanja Modal pemerintah daerah, pemerintah daerah perlu memberikan perhatian khusus dalam bidang investasi swasta. Penelitian ini adalah untuk mengetahui pengaruh pendapatan asli daerah terhadap pertumbuhan ekonomi dengan belanja modal dan investasi swasta sebagai pemoderasi. Dilakukan pada 9kabupaten/kota Provinsi Bali pada tahun 2012-2016. Teknik analisis yang digunakan pada penelitian ini yaitu dengan menggunakan teknik MRA dengan menggunakan program SPSS. Hasil penelitian ini menunjukkan PAD berpengaruh positif terhadap pertumbuhan ekonomi. Belanja Modal memperlemah pengaruh PAD terhadap Pertumbuhan Ekonomi, sedangkan Investasi Swasta memperkuat pengaruh PAD terhadap Pertumbuhan Ekonomi.
\end{abstract}

Kata kunci: pendapatan asli daerah, pertumbuhan ekonomi, belanja modal, investasi swasta.

\begin{abstract}
Economic Growth is one of the indicators to measure the success of economic development in a country. It is expected that with revenue from PAD can increase regional economic growth, increasing $P A D$ can increase local government capital expenditure, local government need to give special attention in private investment field. This research is to know the influence of local income to economic growth with capital expenditure and private investment as moderator. Conducted in 9 districts / cities of Bali Province in 2012-2016. The analysis technique used in this research is by using MRA technique by using SPSS program. The results of this study show that PAD has a positive effect on economic growth. Capital Expenditure weakens the influence of PAD on Economic Growth, while Private Investment strengthens the influence of PAD on Economic Growth.
\end{abstract}

Keywords: local revenue, economic growth, capital expenditure, private investment.

\section{PENDAHULUAN}

Pertumbuhan ekonomi merupakan indikator untuk mengukur keberhasilan pembangunan ekonomi. Pembangunan ekonomi terdiri dari perubahan dalam tingkat pertumbuhan ekonomi, pemberantasan kemiskinan, serta pengurangan ketimpangan pendapatan. Produk domestik regional bruto merupakan indikator untuk mengukur 
pertumbuhan ekonomi dimana mencerminkan jumlah nilai tambah yang dihasilkan dari seluruh aktivitas produksi dalam perekonomian (Febry, et al., 2016). Infrastruktur ekonomi yang digunakan untuk mempasilitasi pertumbuhan ekonomi, meningkatkan sumber daya dan meningkatkan produktivitas ekonomi yang disediakan pemerintah dinyatakan oleh Irene (2014). Ramon, et al. (2010) mendapatkan hasil dimana pengeluaran pemerintah lebih banyak dikaitkan untuk mempercepat pertumbuhan ekonomi serta pengurangan kemiskinan yang lebih besar.

Sistem pemerintahan yang biasa disebut otonomi daerah dapat diartikan dimana pemerintah pusat memberikan wewenang kebebasan untuk pemerintah daerah dalam mengatur rumah tangganya sendiri. Lukman (2004) mengatakan status seseorang akan mempengaruhi kesejahteraan rumah tangga. Dalam sebuah rumah tangga adanya kemiskinan merupakan pengaruh dari pendapatan keluarga yang dapat mempengaruhi pertumbuhan ekonomi (J. Baumol, 2003). Kebijakan yang di dukung mengenai otonomi daerah yang disebutkan pada UU No. 33 tahun 2004 yang awalnya merupakan UU No. 22 tahun 1999 tentang pemerintah daerah dan UU No. 34 tahun 2004 yang awalnya merupakan UU No. 25 tahun 1999 tentang perimbangan keuangan. Menurut Paujiah (2012), undang-undang tersebut menyatakan bahwa pemerintah pusat memberi kebebasan pada pemerintah daerah untuk mengatur rumah tangganya sendiri.

Penerimaan dari PAD diharapkan dapat berdampak terhadap pertumbuhan ekonomi. Akibat dari kenaikan PAD juga menaikkan belanja modal agar kualitas pelayanan publik dapat membaik. Belanja modal diharapkan dapat meningkatkan 
ISSN: 2302-8556

infrastruktur publik, agar dapat meningkatkan pertumbuhan ekonomi. Semakin tinggi tingkat investasi modal maka akan mampu meningkatkan kualitas publik dan dapat meningkatkan partisipan publik terhadap pembangunan. Masyarakat dapat dengan terus meningkatkan kegiatan ekonomi dan kesempatan kerja serta meningkatkan pendapatan nasional dan meningkatkan tarat kemakmuran masyarakat dimana ini memungkinkan untuk kegiatan investasi (Hukubun, et al., 2013).

Investasi yang dilakukan oleh pemerintah daerah dan oleh pihak swasta dapat disebut juga dengan investasi pada daerah, dimana dapat meningkatkan kesejahteraan masyarakat apabila investasi ini dilakukan oleh pihak swasta. Sumber dari investasi yaitu terdapat dari jumlah antara penanaman modal dalam negeri (PMDN) dan penanaman modal asing (PMA). Investasi akan meningkatkan jumlah tenaga kerja apabila investasi berpengaruh terhadap peningkatan kesejahteraan masyarakat dalam publik maupun swasta (Royan, 2015). Dengan menggunakan data deret waktu, Olorunfemi (2008) mempelajari hubungan antara investasi dengan pertumbuhan ekonomi dan mengamati belanja publik berdampak positif pada pertumbuhan ekonomi dan tidak ada hubungan antara pembentukan modal produk domestik regional bruto.

Penelitian yang dilakukan oleh Simanjuntak (2006) dengan judul analisis pengaruh PAD terhadap pertumbuhan ekonomi di Kabupaten Labuhan Batu, dimana mendapatkan hasil bahwa PAD berpengaruh positif dan signifikan terhadap pertumbuhan ekonomi. Dan penelitian Harianto dan Adi (2007) dengan judul hubungan antara DAU, belanja modal, PAD terhadap pertumbuhan ekonomi, dimana 
hasil yang didapatkan bahwa PAD berpengaruh positif dan signifikan terhadap pertumbuhan ekonomi.

Penelitian Anasmen (2009) yang berjudul pengaruh belanja modal terhadap pertumbuhan ekonomi di Sumatera Barat, mendapatkan hasil bahwa belanja modal berpengaruh positif namun tidak signifikan terhadap pertumbuhan ekonomi. Namun Candra (2013) dengan judul pengaruh PAD dan DAU terhadap pertumbuhan ekonomi dengan belanja modal sebagai variabel moderasi, mendapatkan hasil dimana PAD dan DAU berpengaruh positif dan signifikan sedangkan belanja modal berpengaruh negatif atau memperlemah secara signifikan.

Penelitian Aminah (2016) yang berjudul analisis pengaruh investasi swasta dan pengeluaran pemerintah daerah terhadap pertumbuhan ekonomi dan kemiskinan di Provinsi Jambi, mendapatkan hasil bahwa investasi swasta dan pengeluaran pemerintah secara simultan berpengaruh positif dan signifikan terhadap pertumbuhan ekonomi. Rustiyono (2008) dengan judul analisis pengaruh investasi, tenaga kerja, dan pengeluaran pemerintah terhadap pertumbuhan ekonomi di Provinsi Jawa Tengah, mendapatkan hasil dimana antara penanaman modal dalam negeri dan penanaman modal asing berpengaruh positif terhadap pertumbuhan ekonomi.

Penelitian ini dilakukan pada variabel pendapatan asli daerah, belanja modal, investasi swasta, dan pertumbuhan ekonomi, karena dari masing-masing variabel akan sangat berpengaruh satu sama lain. Dimana pendapatan asli daerah dapat mempengaruhi naik turunnya angka produk domestik regional bruto karena dalam penelitian ini untuk mendapatkan hasil dari pertumbuhan ekonomi dimana peneliti 
mengambil hasil dari pengurangan antara angka PDRB tahun sekarang dikurangi angka PDRB tahun sebelumnya dan dibagi PDRB tahun sebelumnya lalu dikalikan dengan 100 persen, maka akan mendapatkan hasil akhir untuk angka pertumbuhan ekonomi. Sedangkan untuk angka pendapatan asli daerah dan belanja modal dimana peneliti mengambil angka dari hasil laporan realisasi anggaran pendapatan belanja daerah Kabupaten/Kota Provinsi Bali, lalu angka tersebut di ln kan agar dapat digunakan untuk melakukan penelitian. Selanjutnya untuk mendapatkan angka dari variabel investasi swasta dimana angka dari penanaman modal dalam negeri dijumlahkan dengan angka dari penanaman modal asing lalu hasilnya dapat di ln kan, maka akan mendapatkan angka untuk melakukan penelitian.

Tujuan dari penelitian ini yaitu untuk mengetahui pengaruh dari pendapatan asli daerah terhadap pertumbuhan ekonomi, mengetahui kemampuan belanja modal memoderasi pengaruh pendapatan asli daerah terhadap pertumbuhan ekonomi, mengetahui kemampuan investasi swasta memoderasi pengaruh pendapatan asli daerah terhadap pertumbuhan ekonomi Kabupaten/Kota di Provinsi Bali. Penelitian ini diharapkan dapat memberikan manfaat teoritis guna dapat menambah wawasan dan pengetahuan yang lebih buas bagi akademis dan dapat memberikan informasi lanjutan dan dijadikan referensi bagi peneliti berikutnya yang serupa dengan penelitian ini. Untuk manfaat praktis dimana hasil penelitian ini diharapkan dapat memberikan informasi penting bagi pemerintah pusat serta pemerintah daerah saat mengelola wilayahnya guna dapat meningkatkan pertumbuhan ekonomi. 
Teori kontijensi merupakan teori yang dapat menyesuaikan pemimpin. Menurut Fiedler's (1967) menyatakan pemahaman pemimpin menentukan kinerja pemimpin. Hubungan antara manajemen dan organisasi dapat meningkatkan kinerja organisasi dan individu (Otley, 1980). Fisher (1998) berpendapat perencanaan dan penggunaan desain sistem pengendalian dipengaruhi oleh karakteristik organisasi dan kondisi lingkungan. Dengan adanya variabel moderasi dalam mempengaruhi variabel bebas dan variabel terikat memungkinkan akan adanya perbedaan dari hasil penelitian (Yukl, 2010:277).

Meckling and Jensen (1976), keagenan dikatakan sebagai kontrak dimana pihak pertama dan pihak kedua mencari pihak ketiga guna melakukan jasa untuk kepentingan pihak pertama dan pihak kedua. Hubungan antara pihak pertama dan pihak kedua terjadi untuk mendapatkan hasil yang bisa dijadikan komitmen masingmasing (Halim dan Abdullah, 2006). Adiwiyana (2011), pemerintah menggunakan teori agensi untuk menyusun rancangan APBD agar mendapatkan hasil dari adanya konflik. Pemerintah pusat memberikan dana perimbangan agar dapat digunakan oleh pemerintah daerah dalam mendanai kebutuhan sehari-hari (Suparyati, 2015). Teori ini juga berhubungan dengan pemerintah dengan rakyat, dimana rakyat menjadi prinsipal guna memberikan sumber kepada pemerintah misalnya pembayaran pajak, namun pemerintah juga harus dapat memberikan perhatian lebih terhadap rakyat yang telah membantu untuk mengembangkan sumber daya.

Barang dan jasa yang digunakan untuk meningkatkan perekonomian disebut pertumbuhan ekonomi (Hasan, 2012). Kondisi perekonomian suatu daerah akan 
ISSN: 2302-8556

makin membaik dari pernyataan merupakan suatu perhitungan pertumbuhan ekonomi (Rahardja dan Manurung, 2008:131). Pajak daerah merupakan sumber terpenting bagi daerah dari empat sumber PAD yaitu pajak daerah, retribusi daerah, BUMD dan pengelolaan kekayaan daerah yang dipisahkan, dan lain-lain PAD yang sah. Menurut Syaiful (2008), belanja modal dikategorikan dalam lima kategori yaitu belanja modal tanah, Belanja modal peralatan mesin, Belanja modal gedung dan bangunan, Belanja modal jalan irigasi dan jaringan, Belanja modal fisik lainnya. Belanja modal juga memiliki dua jenis disebut dengan belanja publik untuk kegiatan investasi dan belanja aparatur yang tidak dapat dirasakan oleh masyarakat.

Investasi swasta terdiri dari investasi fisik dimana pengeluaran yang dapat memberikan hal baru (Mankiw, 2000:24) dan investasi sumber daya dimana berpengaruh terhadap produktivitas dan pendapatan (Schultz, 1961). Modal manusia dapat digunakan untuk proses pembangunan di suatu negara berkembang (Todaro, 2003:405). Pendapatan asli daerah digunakan untuk membiayai belanja daerah, maka dari itu PAD merupakan sumber dari pendapatan daerah. Adanya sumber pendanaan berupa pembangunan infrastruktur dan fasilitas publik yang dinikmati oleh masyarakat harus dapat meningkatkan dan mensejahterakan rakyat. Adanya penelitian yang berjudul sesuai dengan bahasan dimana pendapatan asli daerah berpengaruh terhadap pertumbuhan ekonomi, maka adanya beberapa pendapat dari para peneliti mengenai PAD terhadap pertumbuhan ekonomi dimana beberapa peneliti mendapatkan hasil bahwa PAD bersifat positif terhadap pertumbuhan ekonomi dan PAD berpengaruh terhadap pertumbuhan ekonomi dinyatakan oleh 
Candra (2013), Simanjuntak (2006), Irvan dan Karmini (2016), Eka (2015), dan Febry (2016). Sedangkan hasil penelitian dari Santosa (2013), Tahar dan Maulida (2011), dan Dwi dan Iswan (2013) mendapatkan hasil bahwa pendapatan asli daerah berpengaruh negatif pada pertumbuhan ekonomi.

$\mathrm{H}_{1}$ : pendapatan asli daerah berpengaruh positif terhadap pertumbuhan ekonomi.

Infrastruktur dan sarana publik sangat mempengaruhi pertumbuhan ekonomi disetiap daerah, apabila infrastruktur dan sarana publik baik maka masyarakat akan merasa nyaman saat melaksanakan pekerjaan maka secara langsung tingkat produktibitasnya akan meningkat dan investor akan mencoba untuk berinvestasi. Suatu penelitian yang mengemukakan mengenai hubungan belanja modal dengan pertumbuhan ekonomi mendapatkan hasil bahwa belanja modal berpengaruh positif terhadap pertumbuhan ekonomi dinyatakan oleh Adi (2005), Gathama dan Y. Bagio (2011), Legrenzi and Milas (2001), dan Holtz-Eakin et al (1994). Sedangkan dari hasil penelitian menurut Nugroho dan Abdul (2012) menyatakan bahwa belanja modal berpengaruh negatif terhadap pertumbuhan ekonomi.

$\mathrm{H}_{2}$ : Belanja modal meningkatkan pengaruh positif hubungan antara PAD terhadap pertumbuhan ekonomi.

Investasi adalah pengeluaran oleh pihak swasta untuk membeli barang dan jasa guna menambah persediaan yang akan digunakan untuk memperluas pabrik yang diperlukan (Boediono, 1998). Penanaman modal yang dimiliki dan biasanya diharapkan dapat bermanfaat dimasa yang akan datang disebut investasi (Sunariyah, 2003:4). Dalam jangka panjang pertumbuhan investasi akan berdampak terhadap 
pertumbuhan ekonomi dimana suatu barang dan jasa yang digunakan pada masa sekarang berguna pada masa yang akan datang. Penelitian yang membahas mengenai pengaruh investasi swasta terhadap pertumbuhan ekonomi mendapatkan hasil positif dinyatakan oleh Aminah (2016), Rustiyono (2008), Rika dan Susi (2011), Desnim, et al (2013), Raharjo (2006), Nizar, et al. (2013), Muqsyithu dan Dwisetia (2013), Fatihudin (2011), Saparuddin, et al (2015), Lainatul, et al. (2016), dan Sutawijaya (2010). Sedangkan penelitian yang mendapatkan hasil negatif dinyatakan oleh Tandiawan, et al (2015), Diah dan Purbadharmaja (2015), dan Rinaldi dan Putu (2012).

$\mathrm{H}_{3}$ : Investasi swasta meningkatkan pengaruh positif hubungan antara PAD terhadap pertumbuhan ekonomi.

\section{METODE PENELITIAN}

Pendekatan kuantitatif asosiatif dijelaskan dengan menekankan teori menggunakan variabel penelitian melalui data serta hasil statistik (Indrianto dan Supomo, 2013:12) digunakan sebagai pendekatan dalam penelitian ini. Penelitian asosiatif merupakan suatu penelitian yang mempunyai tujuan mengetahui pengaruh dua variabel atau lebih dan dapat untuk menjelaskan, meramalkan serta memeriksa suatu gejala (Sugiyino, 2016:11). Penelitian ini menggunakan objek penelitian yaitu pengaruh pendapatan asli daerah terhadap pertumbuhan ekonomi dengan belanja modal dan investasi swasta sebagai variabel moderasi. Adapun desain kerangka berpikir dalam penelitian ini disajikan pada Gambar 1. 


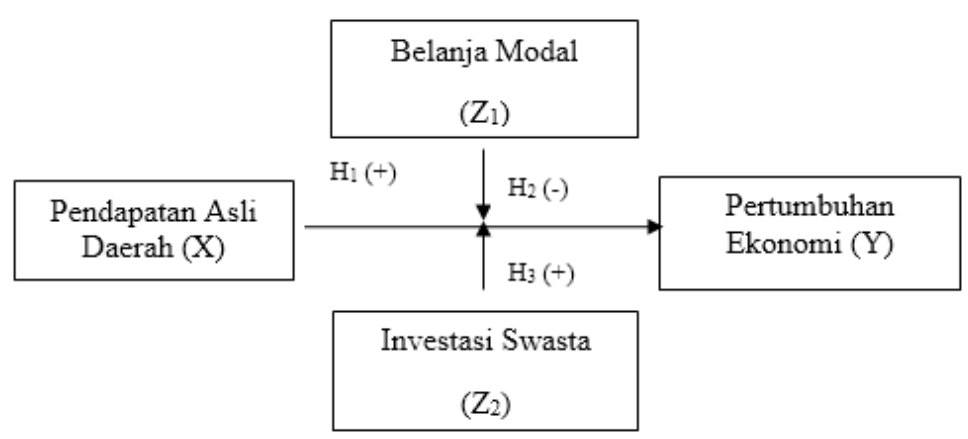

\section{Gambar 1 Desain Penelitian}

Observasi non partisipan digunakan sebagai metode untuk pengumpulan data, dimana metode ini dapat dijelaskan bahwa cara untuk mendapatkan data dari metode ini yaitu dengan melakukan interaksi dengan pihak yang mempunyai data, guna untuk mendapatkan data yang diperlukan maka seorang peneliti harus berhadapan langsung dengan pihak yang menyimpan data untuk amatan dalam penelitian.

Variabel bebas adalah penyebab adanya pengaruh serta adanya perubahan variabel terikat (Sugiyono, 2014:59). Pendapatan asli daerah menjadi variabel bebas dalam penelitian ini. Dapat diukur dengan:

Pendapatan Asli Daerah $(\mathrm{PAD})=\ln \{$ pendapatan asli daerah $\}$

Variabel terikat adalah variabel akibat dari adanya variabel bebas (Sugiyono, 2014:59). Pertumbuhan ekonomo menjadi variabel terikat dalam penelitian ini. Pertumbuhan ekonomi pada penelitian ini menggunakan angka PDRB. Dapat diukur dengan:

$G_{\mathrm{t}}=\frac{\left(P D R B t-P D R B_{\mathrm{t}-1}\right)}{P D R B_{\mathrm{t}-1}} \times 100 \%$ 
ISSN: 2302-8556

Variabel moderasi adalah variabel yang dapat memperlemah atau memperkuat pengaruh dari variabel bebas dan variabel terikat (Sugiyono, 2014:60). Belanja modal akan mempengaruhi pengeluaran yang melewati jarak satu tahun dapat mempengaruhi kekayaan pemerintah dan mempengaruhi anggaran operasional (Mardiasmo, 2009:67). Investasi swasta adalah investasi yang terdiri dari penanaman modal dalam negeri (PMDN) dan penanaman modal asing (PMA) pada suatu negara atau daerah.

Belanja Modal $(\mathrm{BM})=\ln \{$ belanja modal $\}$

Investasi Swasta $(\mathrm{IS})=\ln \{\mathrm{PMDN}+\mathrm{PMA}\}$

Penelitian ini menjadikan laporan realisasi anggaran belanja daerah dan laporan PDRB Bali yang terdiri dari 9 Kabupaten/Kota dengan kurun waktu 5 tahun, dimana tahun yang digunakan 2012-2016 digunakan sebagai populasi dan sampel. Jenis data yang digunakan dalam penelitian ini adalah data kuantitatif dengan sumber data sekunder.

Moderated Regression Analysis (MRA) yang diolah dengan bantuan program SPSS digunakan sebagai teknis analisis data dalam penelitian ini. Model ini dapat digunakan apabila telah memenuhi syarat dengan terbebas dari uji normalitas, uji autokurelasi, uji multikolinearitas, dan uji heterokedastisitas, selanjutnya uji statistik deskriptif, lalu uji MRA, uji kelayakan model (Uji F), koefisien determinasi $\left(\mathrm{R}^{2}\right)$, dan uji hipotesis (Uji t). Model regresi dalam penelitian ini yaitu:

$Y=\alpha+\beta_{1} X+\beta_{2} Z_{1}+\beta_{3} Z_{2}+\beta_{4} X . Z_{1}+\beta_{5} X . Z_{2}+\varepsilon$

Keterangan: 


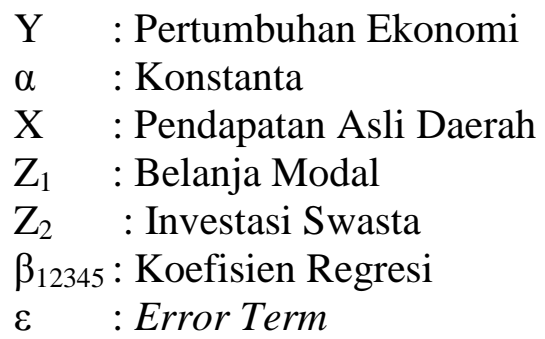

\section{HASIL DAN PEMBAHASAN}

Menjelaskan hasil statistik dalam menganalisa data disebut dengan statistik deskriptif (Sugiyono, 2014:206). Data pada penelitian ini menggunakan data panel, dimana merupakan data yang menggabungkan antara data silang dan data runtun waktu sehingga akan memiliki beberapa objek dan beberapa periode waktu. Hasil statistik dalam penelitian terdapat pada tabel 1 .

\section{Tabel 1.}

Hasil Statistik Deskriptif

\begin{tabular}{lrrrrr}
\hline \multicolumn{1}{r}{ Variabel } & N & Min & Max & Mean & Std. Deviation \\
\hline PE & 45 & 5,43 & 11,43 & 6,7860 & 1,26635 \\
PAD & 45 & 17,52 & 21,99 & 19,2876 & 1,16898 \\
BM & 45 & 17,95 & 20,90 & 19,0747 &, 68946 \\
IS & 45 & 9,66 & 16,57 & 12,8731 & 1,77656 \\
PAD*BM & 45 & 319,76 & 415,74 & 367,9751 & 26,84553 \\
PAD*IS & 45 & 169,24 & 364,46 & 249,9216 & 47,73455 \\
\hline
\end{tabular}

Sumber: Data diolah, 2018

Variabel pertumbuhan ekonomi sebagai variabel terikat memiliki rata-rata sebesar 6,7860 dengan nilai standar deviasi 1,26635. Angka minimum sebesar 5,43 dengan angka maksimum sebesar 11,43. Variabel pendapatan asli daerah (PAD) sebagai variabel bebas memiliki rata-rata sebesar 19,2876 dengan nilai standar deviasi 1,16898. Angka minimum sebesar 17,52 dengan angka maksimum sebesar 21,99. Variabel belanja modal sebagai variabel moderasi pertama memiliki rata-rata 
ISSN: 2302-8556

sebesar 19,0747 dengan nilai standar deviasi 0,68946. Angka minimum sebesar 17,95 dengan angka maksimum sebesar 20,90. Variabel investasi swasta sebagai variabel moderasi kedua memiliki rata-rata sebesar 12,8731 dengan standar deviasi 1,77656. Angka minimum sebesar 9,66 dengan angka maksimum sebesar 16,57. Melakukan pengujian variabel untuk mengetahui data yang digunakan berdistribusi normal atau tidak dapat disebut dengan uji normalitas (Ghozali, 2016:154). Dilihat pada Tabel 2 dimana nilai Asymp. Sig. (2-tailed) sebesar 0,200 maka dapat disimpulkan bahwa seluruh data berdistribusi normal.

\section{Tabel 2.}

Hasil Uji Normalitas

\begin{tabular}{ll}
\hline Kolmogorov-Smirnov & Unstandardized Residual \\
\hline $\mathbf{N}$ & 45 \\
Asymp.Sig(2-tailed) &, 200 \\
\hline
\end{tabular}

Sumber: Data diolah, 2018

Pengujian dalam model regresi linear memiliki korelasi antara kesalahan pada tahun sekarang dengan tahun sebelumnya disebut dengan uji autokorelasi (Ghozali, 2016:107). Jika suatu model regresi mengandung gejala autokorelasi, maka prediksi yang dilakukan dengan model tersebut akan tidak baik atau dapat memberikan hasil prediksi yang menyimpang. Dilihat pada Tabel 3 dimana diperoleh rumus kriteria $\mathrm{dU}<\mathrm{dw}<4-\mathrm{dU}$ yaitu $1,6662<2,141<2,3338$ sesuai dengan tabel Durbin-Waston, maka dapat disimpulkan data yang digunakan bebas dari autokorelasi. 
Tabel 3.

Hasil Uji Autokorelasi

\begin{tabular}{lrrrrr}
\hline $\begin{array}{l}\text { Mode } \\
\mathbf{1}\end{array}$ & $\mathbf{R}$ & $\begin{array}{c}\mathbf{R} \\
\text { Square }\end{array}$ & $\begin{array}{c}\text { Adjusted R } \\
\text { Square }\end{array}$ & $\begin{array}{c}\text { Std. Error of } \\
\text { the Estimate }\end{array}$ & $\begin{array}{c}\text { Durbin- } \\
\text { Watson }\end{array}$ \\
\hline $\mathbf{1}$ &, $938^{\mathrm{a}}$ &, 880 &, 864 &, 46621 & 2,141 \\
\hline
\end{tabular}

Sumber: Data diolah, 2018

Pengujian model regresi apabila ditemukan korelasi antar variabel bebas disebut uji multikolinearitas. Nilai tolerance $\leq 0,10$ atau nilai VIF $\geq 10$ dapat dikatakan bebas dari masalah multikolinearitas. Dapat dilihat pada Tabel 4 dimana angka tolerance dan VIF telah sesuai dengan syarat, maka dapat disimpulkan antar variabel bebas tidak terjadi masalah multikolinearitas.

Tabel 4. Hasil Uji Multikolinieritas

\begin{tabular}{ccc}
\hline Variabel & Tolerance & VIF \\
\hline PAD &, 150 & 6,670 \\
BM &, 756 & 1,323 \\
IS &, 741 & 1,349 \\
\hline
\end{tabular}

Sumber: Data diolah, 2018

Menguji pengamatan satu dengan yang lainnya guna memeriksa ketidaksaam antar varian disebut dengan uji heterokedastisitas. Uji heteroskedastisitas dalam penelitian ini dilakukan dengan cara meregresi nilai absolute residual dari model yang diestimasi terhadap variabel bebas. Jika tingkat signifikan lebih besar dari $\alpha=$ 0,05 maka model regresi yang dianalisis tidak mengandung gejala heterokedastisitas. Dilihat pada Tabel 5 tingkat signifikan semua variabel berada diatas 0,05 maka dapat disimpulkan model regresi ini bebas dari masalah heterokedastisitas. 
ISSN: 2302-8556

E-Jurnal Akuntansi Universitas Udayana

Vol.24.1.Juli (2018): 662-686

Tabel 5.

Hasil Uji Heteroskedastisitas

\begin{tabular}{llcc}
\hline Model & Sig. & Keterangan \\
\hline 1 & (Constant) &, 003 & \\
PAD &, 093 & Bebas Heteroskedastisitas \\
BM &, 568 & Bebas Heteroskedastisitas \\
IS &, 743 & Bebas Heteroskedastisitas \\
PAD*BM &, 769 & Bebas Heteroskedastisitas \\
PAD*IS &, 323 & Bebas Heteroskedastisitas \\
\hline
\end{tabular}

Sumber: Data diolah, 2018

Penelitian ini menggunakan uji MRA guna untuk mengetahui pengaruh variabel moderasi terhadap variabel bebas dengan variabel terikat. Hasil MRA dilihat pada Tabel 6

Tabel 6. Hasil Uji Moderated Regression Analysis

\begin{tabular}{|c|c|c|c|c|c|c|}
\hline & & Unstandardi & Coefficients & $\begin{array}{l}\text { Standardized } \\
\text { Coefficients }\end{array}$ & & \\
\hline & Model & B & Std. Error & Beta & $\mathrm{T}$ & Sig. \\
\hline 1 & (Constant) & $-128,220$ & 47,955 & & $-2,674$ & ,011 \\
\hline & PAD & 6,923 & 2,517 & 6,391 & 2,750 & 009 \\
\hline & BM & 9,704 & 2,455 & 5,283 & 3,953 & ,000 \\
\hline & IS & $-4,606$ &, 542 & $-6,462$ & $-8,501$ & ,000 \\
\hline & $P A D * B M$ &,- 505 & ,129 & $-10,715$ & $-3,928$ &, 000 \\
\hline & PAD*IS & ,247 & ,028 & 9,300 & 8,891 & ,000 \\
\hline & Square $\left(\mathrm{R}^{2}\right)$ & & & & & \\
\hline & cansi F & & & & & \\
\hline
\end{tabular}

Sumber: Data diolah, 2018

$Y=-128,220+6,923 X+9,704 Z_{1}-4,606 Z_{2}-0,505 X_{1}+0,247 X Z_{2}$

Menguji variabel dengan Uji $\mathrm{F}$ di Tabel 6 menunjukkan angka 0,000 berarti karena signifikan F kurang dari 0,05 maka dapat disimpulkan bahwa model regresi ini layang untuk digunakan.

Hasil dari uji koefisien determinasi ditunjukkan dalam Tabel 6 yaitu sebesar 0,864 artinya sebesar 86,4 persen naik turunnya variabel pertumbuhan ekonomi 
dipengaruhi oleh variabel pendapatan asli daerah, belanja modal, dan investasi swasta dan sisanya 13,6 persen dipengaruhi oleh variabel lain diluar model regresi yang digunakan.

Hasil pengujian pada Tabel 6 variabel pendapatan asli daerah menunjukkan nilai Sig. sebesar 0,009 yang artinya $\mathrm{H}_{1}$ diterima dengan nilai koefisien regresi sebesar 6,923 dengan tanda positif, maka kesimpulannya pendapatan asli daerah berpengaruh positif terhadap pertumbuhan ekonomi. Variabel pendapatan asli daerah dihubungkan dengan belanja modal menunjukkan Sig. sebesar 0,000 yang artinya $\mathrm{H}_{2}$ diterima, variabel belanja modal mampu memoderasi dengan nilai sebesar $-0,505$ namun dengan tanda negatif, maka kesimpulannya belanja modal memperlemah pengaruh hubungan pendapatan asli daerah dengan pertumbuhan ekonomi. Variabel pendapatan asli daerah dihubungkan dengan investasi swasta menunjukkan Sig. sebesar 0,000 yang artinya $\mathrm{H}_{3}$ diterima, variabel investasi swasta mampu memoderasi dengan nilai koefisien regresi sebesar 0,247 dengan tanda positif, maka kesimpulannya investasi swasta memperkuat pengaruh hubungan pendapatan asli daerah dengan pertumbuhan ekonomi.

Tingkat signifikan t uji sebesar 0,009 yang menunjukkan angka lebih kecil daripada taraf nyata dalam penelitian ini yaitu 0,05 dengan nilai koefisien regresi pendapatan asli daerah sebesar 6,923. Berdasarkan hasil pengujian pengaruh PAD terhadap pertumbuhan ekonomi yang menunjukkan bahwa pendapatan asli daerah berpengaruh positif dan signifikan terhadap pertumbuhan ekonomi, hasil ini menerima hipotesis $\mathrm{H}_{1}$ yakni Pendapatan Asli Daerah berpengaruh positif dan 
ISSN: 2302-8556

E-Jurnal Akuntansi Universitas Udayana

Vol.24.1.Juli (2018): 662-686

signifikan terhadap Pertumbuhan Ekonomi di Kabupaten/Kota Provinsi Bali. Hasil penelitian ini sejalan dengan hasil penelitian dari Harianto dan Adi (2007), Candra (2013), Simanjuntak (2006), Setiyawati dan Ardi (2007), Priambodo (2013), Srilianti (2013), dan Febry (2016).

Variabel interaksi PAD dengan belanja modal memiliki hasil $-0,505$ dengan signifikansi sebesar 0,000 yang lebih kecil dari tingkat signifikansi 0,05. Berdasarkan hasil pengujian kemampuan belanja modal memoderasi pengaruh PAD terhadap pertumbuhan ekonomi yang menunjukkan bahwa belanja modal memperlemah pengaruh PAD terhadap pertumbuhan ekonomi, hasil ini menerima hipotesis $\mathrm{H}_{2}$ yakni Belanja Modal memperlemah dan bersifat signifikan pada hubungan antara Pendapatan Asli Daerah terhadap Pertumbuhan Ekonomi di Kabupaten/Kota Provinsi Bali. Hasil penelitian ini sejalan dengan hasil penelitian Candra (2013), dan Paujiah (2012). Namun hasil penelitian ini tidak sejalan dengan Holtz-Eakin, et al. (1994), Legrenzi and Milas (2001), dan Adi (2005) yang mendapatkan hasil positif antara hubungan belanja modal dengan pertumbuhan ekonomi.

Variabel interaksi PAD dengan investasi swasta memiliki hasil sebesar 0,247 dengan signifikansi 0,000 yang lebih kecil dari tingkat signifikansi 0,05. Berdasarkan hasil pengujian kemampuan investasi swasta memoderasi pengaruh PAD terhadap pertumbuhan ekonomi yang menunjukkan bahwa investasi swasta memperkuat pengaruh PAD terhadap pertumbuhan ekonomi, hasil ini menerima hipotesis $\mathrm{H}_{3}$ yakni Investasi Swasta memperkuat dan bersifat signifikan pada hubungan antara Pendapatan Asli Daerah terhadap Pertumbuhan Ekonomi di Kabupaten/Kota Provinsi 
Bali. Hasil penelitian ini sejalan dengan hasil penelitian Aminah (2016), Weya, et al., Sjafii (2009), dan Agustini dan Erni (2017). Namun tidak sejalan dengan penelitian Hukubun (2013) dan Brigita, et al. (2016) yang mendapatkan hasil negatif antara hubungan investasi swasta dengan pertumbuhan ekonomi.

\section{SIMPULAN}

Berdasarkan hasil penelitian yang dijelaskan, maka didapatkan simpulan dimana Pendapatan asli daerah berpengaruh positif dan signifikan terhadap pertumbuhan ekonomi di Kabupaten/Kota Provinsi Bali. Hal ini terjadi karena semakin tinggi PAD maka akan semakin bagus pertumbuhan ekonomi di Bali. Belanja modal sebagai moderasi memperlemah pengaruh hubungan antara pendapatan asli daerah terhadap pertumbuhan ekonomi Kabupaten/Kota Provinsi Bali. Hal ini kemungkinan diakibatkan pemerintah daerah masih kurang maksimal dalam melakukan kajian serta pemeriksaan atas penggunaan belanja modal pada masing-masing daerah. Investasi swasta sebagai moderasi memperkuat pengaruh hubungan antara pendapatan asli daerah terhadap pertumbuhan ekonomi Kabupaten/Kota Provinsi Bali. Penanaman modal dari investor swasta yang secara merata di Kabupaten/Kota Provinsi Bali yang mengakibatkan adanya penerapan tenaga kerja, sehingga dapat mempengaruhi PAD terhadap pertumbuhan ekonomi.

Saran yang didapat dari hasil penelitian dimana Pemerintah daerah agar dapat mengoptimalkan sumber-sumber PAD dan menarik sebanyak-banyaknya penanaman modal dari investor swasta, sehingga dapat memperkuat pengaruh hubungan antara PAD terhadap pertumbuhan ekonomi. Dengan demikian alokasi belanja modal dari 
ISSN: 2302-8556

E-Jurnal Akuntansi Universitas Udayana

Vol.24.1.Juli (2018): 662-686

pemerintah akan semakin kecil, apabila hal ini diperlukan agar mengoptimalkan kajian-kajian dari pihak akademisi.

\section{REFERENSI}

Adi, Priyo Hari. 2005. Dampak Desentralisasi Fiskal terhadap Pertumbuhan Ekonomi (Studi pada Kabupaten dan Kota Se Jawa Bali). Jurnal Studi Pembangunan Kritis. Universitas Kristen Satya Wacana. Salatiga.

Adiwiyana, Priya. 2011. Pengaruh Pertumbuhan Ekonomi, Pendapatan Asli Daerah, dan Dana Alokasi Umum Terhadap Pengalokasian Anggaran Belanja Modal. Skripsi. Fakultas Ekonomi Universitas Diponogoro, Semarang.

Agustini, Yetty dan Erni Panca Kurniasih. 2017. Pengaruh Investasi PMDN, PMA, dan Penyerapan Tenaga Kerja terhadap Pertumbuhan Ekonomi dan Jumlah Penduduk Miskin Kabupaten/Kota di Provinsi Kalimantan Barat. Jurnal Ekonomi Bisnis dan Kewirausahaan. 6(2), pp: 97-119.

Aminah, Siti. 2016. Analisis Pengaruh Investasi dan Pengeluaran Pemerintah Daerah terhadap Pertumbuhan Ekonomi dan Kemiskinan di Provinsi Jambi. 4(2), pp: 119-130.

Anasmen. 2009. Pengaruh Belanja Modal Pemerintah terhadap Pertumbuhan Ekonomi di Provinsi Sumatera Barat 2000-2006. Tesis. Fakultas Ekonomi Program Studi Perencanaan dan Kebijakan Publik Kekhususan Ekonomi Keuangan Negara dan Daerah Universitas Indonesia.

Boediono. 1998. Teori Pertumbuhan Ekonomi, Seri Sinopsis, Pengantar Ilmu Ekonomi, No. 4, Edisi Pertama. Yogyakarta: BPFE.

Brigita, Gabriela Desire Mosey, Rosalina Koleangan, dan Richard Tumilaar. 2016. Pengaruh Investasi Swasta dan Pengeluaran Pemerintah terhadap Pertumbuhan Ekonomi di Kabupaten Minahasa Utara tahun 2004-2013. Jurnal Berkala Ilmiah Efisiensi. 16(1).

Candra, Gunantara. 2013. Pengaruh Pendapatan Asli Daerah dan Dana Alokasi Umum terhadap Pertumbuhan Ekonomi dengan Belanja Modal sebagai Variabel Pemoderasi di Provinsi Bali. Skripsi. Fakultas Ekonomi dan Bisnis Universitas Udayana.

Desnim, Engla Silvia, Yunia Wardi, dan Hasdi Aimon. 2013. Analisis Pertumbuhan Ekonomi, Investasi, dan Inflasi di Indonesia. Jurnal Kajian Ekonomi. 1(2), pp: 224-243. 
Diah, Paramita A.A. Istri, dan Purbadharmaja, I.B. Putu. 2015. Pengaruh Investasi dan Pengangguran terhadap Pertumbuhan Ekonomi serta Kemiskinan di Provinsi Bali. E-Jurnal Ekonomi Pembangunan Universitas Udayana. 4(10), pp: 1194-1327.

Dwi, Febrian Prakarsa, dan Iswan Noor. 2013. Analisis Pengaruh Pendapatan Asli Daerah dan Pengeluaran Pemerintah Daerah terhadap Pertumbuhan Ekonomi. Jurnal Ilmiah Mahasiswa Fakultas Ekonomi dan Bisnis Universitas Brawijaya. 2(2).

Eka, Zuwesty Putri. 2015. Analisis Pengaruh Pendapatan Asli Daerah, Dana Alokasi Umum dan Inflasi terhadap Pertumbuhan Ekonomi di Kabupaten/Kota Provinsi Jawa Timur. Jurnal Bisnis dan Manajemen. 5(2), pp: 173-186.

Fatihudin, Didin. 2011. Pengaruh Investasi Swasta dan Investasi Pemerintah terhadap Pertumbuhan Ekonomi, Penyerapan Tenaga Kerja dan Tingkat Kesejahteraan Masyarakat Kabupaten/Kota di Provinsi Jawa Timur. Tesis. Universitas Airlangga.

Febry, Chindy Rori, Antonius Y Luntungan, dan Audie O Niode. 2016. Analisis Pengaruh Pendapatan Asli Daerah (PAD) terhadap Pertumbuhan Ekonomi di Provinsi Sulawesi Utara tahun 2001-2013. 16(2), pp: 243-254.

Fiedler, F. E. 1967. A Theory of Leaderships Effectiveness, Mc Graw-Hill Book Company. New York. p.159.

Fisher, Josept G. 1998. "Contingency Theory, Management Control Systems and Firm Outcomes: Past Results and Future Directions". Behavioral Research in Accounting, 10, p.47-64.

Gathama, Norista Putra, dan Y. Bagio Mudakir MSP. 2011. Pengaruh Belanja Modal dan Belanja Operasi terhadap Laju Pertumbuhan Ekonomi di Provinsi Jawa Tengah. Fakultas Ekonomi Universitas Diponegoro Semarang.

Ghozali, Imam. 2016. Aplikasi Analisis Multivariate Dengan Program IBM SPSS 23. Semarang: Badan Penerbit Universitas Diponogoro.

Halim, Abdul dan Syukriy Abdullah. 2006. Hubungan dan Masalah Keagenan di Pemerintah Daerah: Sebuah Peluang Penelitian Anggaran dan Akuntansi. Jurnal Akuntansi Pemeirntah, 2(1), pp: 53-64.

Harianto dan Adi. 2007. Hubungan antara Dana Alokasi Umum, Belanja Modal, Pendapatam Asli Daerah, dan Pendapatan Per Kapita. Fakultas Ekonomi Universitas Kristen Satya Wacana Salatiga. 
ISSN: 2302-8556

E-Jurnal Akuntansi Universitas Udayana

Vol.24.1.Juli (2018): 662-686

Hasan, T.I.B. 2012. Pengaruh Belanja Modal Pemerintah dan Produk Domestik Regional Bruto terhadap Penduduk Miskin di Aceh. Journal SAINS Riset, $1(1)$.

Holtz-Eakin, Doglas, Harvey S, and Schuyley Tilly. 1994. Intertempora Analysis of State An Local Government Spending: Theory and Tests. Journal of Urban Economics. 35, pp:159-174.

Hukubun, Mefi, Debby Rotinsulu dan Audie Niode. 2013. Pengaruh Investasi Pemerintah dan Investasi Swasta terhadap Pertumbuhan Ekonomi dan Dampaknya terhadap Tenaga Kerja Provinsi Sulawesi Utara tahun 2002-2012. Skripsi. Fakultas Ekonomi dan Bisnis, Jurusan Ekonomi Pembangunan Universitas Sam Ratulangi, Manado.

Indriantoro, Nur. Supomo, Bambang. 2013. Metodologi Penelitian Bisnis Untuk Akuntansi \& Manajemen. Yogyakarta: BPFE Yogyakarta.

Irene, Kambua N. 2014. Effects of Government Spending On Economic Growth in Kenya. Department of Finance and Accounting. University of Nairobi.

Irvan, I Putu, dan Ni Luh Karmini. 2016. Pengaruh Pendapatan Asli Daerah, Dana Perimbangan terhadap Pertumbuhan Ekonomi dengan Belanja Modal sebagai Variabel Intervening. E-Jurnal Ekonomi Pembangunan Universitas Udayana. 5(3), pp: 316-384.

J. Baumol, W and Alan S. Bhinder. 2003. Economic Principles and Policy ninth edition. United Stated Of America.

Lainatul, Reza Rizky, Grisvia Agustin, dan Imam Mukhlis. 2016. Pengaruh Penanaman Modal Asing, Penanaman Modal Dalam Negeri dan Belanja Modal terhadap Pertumbuhan Ekonomi Provinsi di Indonesia. JESP. 8(1), pp: 9-16.

Legrenzi, Gabriella and Coctas Milas. 2001. Non-Linier and Asymmetric Adjusment The Local Revenue-Expenditure Models: Some Evidence from The Italian Municipalities. University of Milan, Working Paper.

Lukman, Lusiana. 2004. The Impact of Goverment Expenditure on Poverty Reduction in Indonesia. Journal of Economic and Bussiness, 3(1), pp:51-57.

Mankiw, N. Gregory. 2000. Teori Ekonomi Makro, Edisi Keempat. Penerbit Erlangga, Jakarta.

Mardiasmo. 2009. Akuntansi Sektor Publik. Yogyakarta: ANDI. 
Meckling, WH. dan Jensen, MC. 1976. Theory of the Firm: Manajerial Behavior, Agency Cost and Ownership Structure. Journal of Financial Economics 3, 1976.

Muqsyithu, Bambang Wihda, dan Dwisetia Poerwono. 2013. Analisis Pengaruh Penanaman Modal Dalam Negeri, Penanaman Modal Asing, Pengeluaran Pemerintah dan Tenaga Kerja terhadap Pertumbuhan Ekonomi di Yogyakarta. Fakultas Ekonomika dan Bisnis Universitas Diponegoro.

Nizar, Chairul,Abubakar Hamzah, dan Sofyan Syahnur. 2013. Pengaruh Investasi dan Tenaga Kerja terhadap Pertumbuhan Ekonomi serta hubungannya terhadap Tingkat Kemiskinan di Indonesia. Jurnal Ilmu Ekonomi Pascasarjana Universitas Syiah Kuala. 1(2), pp: 1-8.

Nugroho, Fajar dan Abdul Rohman. 2012. Pengaruh Belanja Modal terhadap Pertumbuhan Kinerja Keuangan Daerah dengan Pendapatan Asli Daerah sebagai Variabel Intervening. Jurnal Akuntansi Universitas Diponegoro. 1(2), pp: $1-14$.

Olorunfemi, S. 2008. Public Investment and Economic Growth in Nigeria: An Autoregresive Model. Journal of International Finance and Economics, 11, pp:50-67.

Otley, David. 1980. The Contingency Theory of Management Accounting: Achievement and Prognosis. Accounting Organization and Society. Vol. 5. p.413-428.

Paujiah, Sri Puji. 2012. Pengaruh Pendapatan Asli Daerah (PAD) dan Dana Alokasi Umum (DAU) terhadap Belanja Modal. Skripsi. Fakultas Ekonomi Jurusan Akuntansi Universitas Siliwangi, Tasikmalaya.

Priambodo, Agung. 2013. Analisis Pengaruh Pendapatan Asli Daerah (PAD), Belanja Modal, dan Tenaga Kerja terhadap Pertumbuhan Ekonomi Kabupaten/Kota di Provinsi Jawa Tengah tahun 2008-2012. Jurnal Ekonomi Pembangunan, Fakultas Ekonomi Universitas Negeri Semarang.

Raharja, Prathama dan Mandala Manurung. 2008. Teori Ekonomi Makro Suatu Pengantar. Jakarta: Lembaga Penerbit FE-UI.

Raharjo, Adi. 2006. Pengaruh Pengeluaran Pemerintah, Investasi Swasta dan Angkatan Kerja terhadap Pertumbuhan Ekonomi tahun 1982-2003. Tesis. Program Pascasarjana Universitas Diponegoro Semarang. 
ISSN: 2302-8556

E-Jurnal Akuntansi Universitas Udayana

Vol.24.1.Juli (2018): 662-686

Ramon, Vinod, and Yan. 2010. Effect of Ficla Policies on the Quality of Growth. International Journal of Economic Studies, 9, pp:112-134.

Republik Indonesia, Undang-Undang No. 32 tahun 2004 tentang Pemerintah Daerah.

Republik Indonesia, Undang-Undang No. 33 tahun 2004 tentang Perimbangan Keuangan Antara Pemerintah Pusat dan Pemerintah Daerah.

Rika, Darma Swaramarinda, dan Susi Indriani. 2011. Pengaruh Pengeluaran Konsumsi dan Investasi Pemerintah terhadap Pertumbuhan Ekonomi di Indonesia. Fakultas Ekonomi Universitas Negeri Jakarta. EconoSains. 9(2), pp: 95-105.

Rinaldi, Rafli, dan Putu Mahardika Adi Saputra. 2012. Analisis Pengaruh Konsumsi Pemerintah, Investasi Pemerintah, Investasi Swasta, dan Angkatan Kerja terhadap Pertumbuhan Ekonomi Regional. Jurnal Ilmiah Mahasiswa Fakultas Ekonomi dan Bisnis Universitas Brawijaya. 1(2).

Royan, Mohamad Miftahur, Aisah Jumiati, dan Fajar Wahyu Prianto. 2015. Pengaruh Investasi Publik dan Swasta Terhadap Peningkatan Indeks Pembangunan Manusia (IPM) Di Jawa Timur, Artikel Ilmiah Mahasiswa 2015.

Rustiyono, Deddy. 2008. Analisis Pengaruh Investasi, Tenaga Kerja, dan Pengeluaran Pemerintah terhadap Pertumbuhan Ekonomi di Provinsi Jawa Tengah. Semarang.

Santosa, Budi. 2013. Pengaruh Pendapatan Asli Daerah dan Dana Perimbangan Daerah terhadap Pertumbuhan, Pengangguran, dan Kemiskinan 33 Provinsi di Indonesia. Jurnal Keuangan dan Bisnis Program Studi Magister Manajemen Sekolah Tinggi Ilmu Ekonomi Harapan. 5(2), pp: 130-143.

Saparuddin, Selly Yolanda, and Karuniana Dianta A. Sebayang. 2015. Effect Invesment and The Rate of Inflation to Economic Growth in Indonesia. Fakultas Ekonomi Negeri Jakarta. Trikonomika. 14(1), pp: 87-95.

Schultz, Theodore W. 1961. Investment in Human Capital. American Economic Review, 36(3), pp: 12.

Setiyawati, Anis, dan Ardi Hamzah. 2007. Analisis Pengaruh PAD, DAU, DAK, dan Belanja Pembangunan terhadap Pertumbuhan Ekonomi, Kemiskinan, dan Pengangguran: Pendekatan Analisis Jalur. Jurnal Akuntansi dan Keuangan Indonesia. 4(2), pp: 211-228. 
Simanjuntak. 2006. Pengaruh Pendapatan Asli Daerah terhadap Pertumbuhan Ekonomi di Kabupaten Labuhan Batu. Tesis. Sekolah Pascasarjana Universitas Sumatera Utara.

Sjafii, Achmad. 2009. Pengaruh Investasi Fisik dan Investasi Pembangunan Manusia terhadap Pertumbuhan Ekonomi Jawa Timur 1990-2004. Jurnal Fakultas Ekonomi Universitas Airlangga, Surabaya. 3(1), pp: 59-76.

Srilianti, Winda Mamonto. 2013. Pendapatan Asli Daerah (PAD) dan Tenaga Kerja Pengaruhnya terhadap PDRB Kota Kotamobagu periode 2002-2011. Jurnal EMBA. 1(4), pp: 1198-1207.

Sugiyono. 2014. Metode Penelitian Bisnis. Bandung: Alfabeta. . 2016. Metode Penelitian Administrasi. Bandung: Alfabeta

Sunariyah. 2003. Pengantar Pengetahuan Pasar Modal. Yogyakarta: YKPN.

Suparyati, Agustina dan Nurul Fadilah. 2015. Dampak Economic Freedom terhadap Pertumbuhan Ekonomi Negara Asia. Fakultas Ekonomi Universitas Trisakti. Jakarta.

Sutawijaya, Adrian. 2010. Pengaruh Ekspor dan Investasi terhadap Pertumbuhan Ekonomi Indonesia tahun 1980-2006. Jurnal Organisasi dan Manajemen. Fakultas Ekonomi Universitas Terbuka Jakarta. 6(1), pp:14-27.

Syaiful. 2008. Pengertian dan Perlakuan Akuntansi Belanja Barang dan Belanja Modal Dalam Kaidah Akuntansi Pemerintahan. www.bappenas.go.id

Tahar, Afrizal, dan Maulida Zakhiya. 2011. Pengaruh Pendapatan Asli Daerah dan Dana Alokasi Umum terhadap Kemandirian Daerah dan Pertumbuhan Ekonomi Daerah. Jurnal Akuntansi dan Investasi. 12(1), pp: 88-99.

Tandiawan, Elvandry, Amran Naukoko, dan Patrick Wauran. 2015. Pengaruh Investasi Swasta dan Belanja Pemerintah terhadap Pertumbuhan Ekonomi dan Dampaknya terhadap Kesempatan Kerja di Kota Manado tahun 2001-2012. Jurnal Berkala Ilmiah Efisiensi. 15(1), pp: 181-196.

Todaro, MP. dan Smith, SC. 2003. Economic Development. Eighth Edition. Pearson Education Limited. United Kingdom. Haris Munandar dan Puji A.L. (penterjemah) 2004. Pembangunan Ekonomi di Dunia Ketiga. Edisi Kedelapan. Penerbit Erlangga. Jakarta. 
Weya, Yandiles, Vecky A.J. Masinambow, dan Rosalina A.M. Koleangan. Analisis Pengaruh Investasi Swasta, Pengeluaran Pemerintah, dan Penduduk terhadap Pertumbuhan Ekonomi di Kota Bitung. Jurnal Fakultas Ekonomi dan Bisnis, Magister Ilmu Ekonomi Universitas Sam Ratulangi, Manado.

Yukl, Gary. 2010. Kepemimpinan dalam Organisasi, Edisi kelima. Jakarta: PT. Indeks. 